Original Research Article

\title{
Increased beneficial outcome of metformin by co-enzyme Q10 against experimentally-induced hind limb ischemia reperfusion injury in normal and diabetic rats
}

\author{
Eman A. Abdel-Aziz, Heba A. Elnoury*
}

Department of Pharmacology, Faculty of Medicine, Benha University, Egypt

Received: 21 February 2019

Revised: 16 March 2019

Accepted: 03 April 2019

*Correspondence to:

Dr. Heba A. Elnoury,

Email:

hebaalnoury81@gmail.com

Copyright: (C) the author(s), publisher and licensee Medip Academy. This is an openaccess article distributed under the terms of the Creative Commons Attribution NonCommercial License, which permits unrestricted noncommercial use, distribution, and reproduction in any medium, provided the original work is properly cited.

\begin{abstract}
Background: Skeletal muscles are susceptible for ischemic reperfusion injury especially in settings in order to achieve homeostasis in traumatic injury and vascular surgery. This study aimed at investigating the implication of induction of diabetes on generation of ischemic reperfusion injury in rat gastrocnemius muscle. In addition, the possible beneficial effect of metformin and co-enzyme q10 was investigated.

Methods: About 80 male adult Sprague Dawley rats divided into 10 groups. Metformin was administrated as continuous oral dose for 28 days. Coenzyme q10 was administrated parenterally 2 and 24 hours before induction of ischemia in diabetic and non-diabetic animals.

Results: In diabetic ischemic groups, tested drugs either singly or in combination significantly reduce $\mathrm{HB} 1 \mathrm{cA}$ and plasma levels of muscle specific enzyme CPK and muscle myokin IL6, raised natural antioxidant GSH and reduced oxidative stress parameters (SOD and MDA), apoptotic (caspase-3) and inflammatory parameters TNF- $\alpha$ and TGF $\beta$ were reduced. Continuous oral metformin for 28 days was more powerful than parenteral short-term coenzyme q10 as regards all tested parameters except for GSH and caspase-3 both drugs were equi-effective. Combined drugs have more powerful ameliorating effect than either drug singly except for HB1cA which was equi-effective with that of metformin. Regarding non diabetic ischemic groups, metformin was more powerful in reduction of caspase-3, IL6 and TNF- $\alpha$ while coenzyme q10 was more powerful in elevating GSH.
\end{abstract}

Conclusions: Co-enzyme q10 can be used as add on therapy with metformin in order to decrease the deleterious effects resulted from hind limb ischemia reperfusion in normal and diabetic rats.

Keywords: Co-enzyme q10, Ischemia reperfusion, Metformin, Rats

\section{INTRODUCTION}

Ischemic reperfusion injury means the tissue damage occurred when blood flow returns to tissue after a period of ischemia or lack of oxygen. deprivation of oxygen and nutrients during the period of ischemia results in a condition in which restoration of circulation leads to inflammation and oxidative damage of the tissues through oxidative stress induction rather than (or along with) restoration of normal function. It is a serious problem because it doesn't only affect local tissue but can also result in life-threatening damage to many organs. ${ }^{1}$ Skeletal muscles are a common target for ischemic reperfusion injury due to predominant anaerobic metabolism during prolonged muscular contraction.

Moreover, normal muscle perfusion is deliberately interrupted through application of tourniquets in cases of vascular surgery and management of hemorrhage. ${ }^{2}$ Using of arterial tourniquet is clinically common in both trauma 
and other clinical settings for achieving hemostasis. However, it may induce ischemia-reperfusion injury which greatly limits the clinical utilization of the tourniquet. $^{2}$

Susceptibility to ischemia reperfusion injury is increased in diabetes mellitus especially in skeletal muscles as a result of wide spread small and large vessel diseases due to accelerated atherosclerosis, activation of aldose reductase pathway and accumulation of advanced glycated end products. It is a major risk factor for cellular inflammation and oxidative stress. ${ }^{3}$

In this work, the implication of induction of diabetes on generation of ischemic reperfusion injury in rat gastrocnemius model was investigated. The abovementioned tissue represents a highly vulnerable site of this ischemic reperfusion injury. In addition, the possible beneficial effect of metformin and co-enzyme q10 was investigated.

The choice of such drugs stems from the fact that they activate important anaerobic defense mechanisms against reperfusion injury namely AMP kinase and mitochondrial hydrogen transport. ${ }^{4}$ The dosage regimens based on pilot experiments. They lie within human therapeutic range after conversion to rat dose using pajet and barns. ${ }^{5}$

For fulfilment of the above-mentioned goals the following parameters were investigated. Glycated hemoglobin (Hb1AC), serum level of muscle specific enzyme CPKMM and a muscle specific cytokine (myokin) namely IL6, inflammatory parameters namely transforming growth factor beta (TGF- $\beta$ ), tumor necrosis factor alpha (TNF- $\alpha$ ), oxidative state parameters namely estimation of reduced glutathione (GSH), malondialdehyde (MDA) and superoxide dismutase (SOD) activity as well as caspase-3 level as an indicator of apoptosis in skeletal muscle homogenates.

\section{METHODS}

\section{Drugs and chemicals}

Coq 10 was purchased (MP Biomedicals, OH, USA). Metformin (Merck, Germany). Both in powder form. All drugs were dissolved in water and were freshly prepared before use. Phosphate and citrate buffer were purchased from (Sigma Chemicals, St. Louise, USA).

\section{Animals}

Total 80 male adult Sprague Dawley rats weighing 150$200 \mathrm{~g}$ were obtained from experimental animal breeding farm, (Helwan-Cairo).

They were caged 8 per cage in well ventilated place at room temperature in animal house at Department of Pharmacology, Benha Faculty of Medicine, Benha University, Egypt.
They allowed free water and standard food for 7 days for acclimatization. During the whole period of experiment, animals were treated humanically according to the protocol of handling of experimental animals of Benha faculty of medicine, Benha University, Egypt.

\section{Animal grouping}

Rats were divided into 10 weight matched groups of 8 animals.

\section{Group I}

Normal control (non -diabetic, no ischemia).

\section{Group II}

Non diabetic ischemic group (I/R) in which rats were subjected to 2 hours of ischemia followed by 2 hours of reperfusion. The animals were initially anesthetized with intraperitoneal pentobarbital and their hind leg shaved. They were subjected to 2 hours of ischemia of their hind limbs using the Tourni-Cot method followed by 2 hours of reperfusion. Limb perfusion before and after the TourniCot method was confirmed via a laser doppler unit. ${ }^{6}$

\section{Group III}

Diabetic (no ischemia) (DM) was served to investigate the effect of induction of diabetes mellitus by a single I.P. injection of streptozotocin (STZ) $(65 \mathrm{mg} / \mathrm{kg}$ body weight), 15 minutes (min) after I.P. administration of nicotinamide (NAD) $(110 \mathrm{mg} / \mathrm{kg})$ on tested parameters. Serum glucose concentration was measured after 72 hours and on the $7^{\text {th }}$ day of start of experiment. The animals which showed non fasting glucose concentration more than $250 \mathrm{mg} / \mathrm{dl}$ were considered diabetic and enrolled in experiment. Others were excluded. ${ }^{7}$

\section{Group IV}

Diabetic ischemic group $(\mathrm{DM}+\mathrm{I} / \mathrm{R})$ in which diabetes was induced as group II and hind limb ischemic reperfusion injury was induced after 28 days of induction of diabetes

\section{Group V}

Non diabetic ischemic group+co-enzyme q10 (I/R+Q10) in which co-enzyme q10 was administrated at a dose of 20 $\mathrm{mg} / \mathrm{kg}$ intramuscular (I.M.) in gluteal muscles and 10 $\mathrm{mg} / \mathrm{kg}$ intraperitoneally (I.P.) at 24 hours and 2 hours before ischemic reperfusion injury according to protocol suggested by Miles MV. ${ }^{8}$

\section{Group VI}

Non diabetic ischemic group+metformin (I/R+Met). The tested drug was administrated in a dose of $(150 \mathrm{mg} / \mathrm{kg}$ bw/day P.O.) for 28 days before ischemic reperfusion injury. 


\section{Group VII}

Non diabetic ischemic group+co-enzyme q10+metformin (I/R+Q10+Met), in which I/R was induced as group II and tested drug were administrated as group V and VI.

\section{Group VIII}

Diabetic ischemic group+co-enzyme q10 (D.M+I/R+Q10) in which diabetes mellitus was induced as group III and tested drug was administrated as group $\mathrm{V}$ on $27^{\text {th }}$ and $28^{\text {th }}$ from induction of diabetes.

\section{Group IX}

Diabetic ischemic group+metformin $(\mathrm{DM}+\mathrm{I} / \mathrm{R}+\mathrm{Met})$. In which diabetes mellitus was induced as group III and tested drug was administrated as group VI after 28 days of induction of diabetes.

\section{Group X}

Diabetics ischemic group+co-enzyme q10+metformin (DM+I/R+Q10+Met). In which diabetes mellitus was induced as group III, Q10 and metformin were given as in group VIII and IX respectively.

\section{Procedure}

- Diabetes mellitus was induced in group III, IV, VIII, IX, X by NAD and STZ as previously described.

- Metformin was administrated to groups VI, VII, IX, $\mathrm{X}$ orally for 28 days.

In $27^{\text {th }}$ day of experiment, Q10 was administrated in groups V, VII, VIII and X as single I.M. injection.

At the end of the study (28 days after induction of diabetes). Another I.M. injection of Q10 was administrated to groups V, VII, VII and X. Then ischemia reperfusion was by Tourni-Cot method. ${ }^{6}$

- All rats then were fixed on operating table and the blood samples were taken from the heart by the technique described by Parasuraman $\mathrm{S}$ et al. ${ }^{9}$ Blood samples were incubated at $37^{\circ} \mathrm{C}$ until blood clotted and then centrifuged at 3000 revolution per minute (rpm) for $15 \mathrm{~min}$ for separation of serum and analysis of tested biochemical parameters.

Tissue samples $(0.5 \mathrm{~g})$ were obtained from gastrocnemius muscle in both limbs of each animal. They were washed in saline and used for preparation of muscle tissue homogenates. They were homogenized in a phosphate buffer $(1: 10 \mathrm{w} / \mathrm{v}, \mathrm{pH} 7.4)$ using iced glass homogenizer. The homogenates were centrifuged at $15000 \mathrm{~g}$ for 10 minutes at $4^{\circ} \mathrm{C} .100 \mu \mathrm{l}$ was kept at $4^{\circ} \mathrm{C}$ and used for determination of total protein of the samples using Bradford assay. ${ }^{10}$ The rest of supernatant was stored at $80^{\circ} \mathrm{C}$ for determination of oxidative and apoptotic parameters.

\section{Biochemical analysis of serum level of CPK}

It was determined by ELISA using commercially available kits (RAT CK-MM ELISA KIT, life diagnostic, Inc., P.O. Box 5205, West Chester, PA.) according to the manufacturer's instructions.

\section{Serum levels of TNF- $\alpha$}

It was measured by ELISA using commercially available kits according to the manufacturer's instructions (Quantikine HS, R and D Systems, Minneapolis, MN, USA).

\section{Serum TGF-ß1 levels}

It was measured by quantitative sandwich ELISA using kits supplied from R and D Systems (Europe, Ltd., United Kingdom).

\section{Determination of serum concentration of $I L-6$}

IL-6 content in serum was measured according to Nolan Y et al, by solid phase ELISA using a rat IL-6 kit (Ray Biotech, Norcross, USA). ${ }^{11}$

\section{Measurement of MDA and SOD}

SOD was assessed spectrophotometrically. ${ }^{12}$ MDA level was measured according to the method of Esterbauer and Cheeseman spectrophotometrically. ${ }^{13}$

\section{Measurement of reduced glutathione (GSH)}

GSH level was measured by colorimetric method. ${ }^{14}$

\section{Measurement of caspase-3 concentration in muscle tissue homogenate}

Quantitative determination of tissue caspase-3 was measured using Correlate-Assay, Caspase-3 Colorimetric Assay Kit, (Catalog no. 907-013). ${ }^{15}$

Results are presented as mean \pm standard deviation $($ mean \pm SD). Statistical analysis was performed using oneway analysis of variance (ANOVA) to detect over all significant differences between the group means followed by t-test to detect difference between individual groups probability $(\mathrm{P})$ values of $<0.05$ were considered as statistically significant.

\section{RESULTS}

In this work, experimental induction of diabetes mellitus type II and or hind limb I/R in rats resulted in significant increase of serum level of TGF- $\beta 1$ (Table 1), IL-6 and 
TNF- $\alpha$ (Table 2) in association with significant increase of tissue SOD activity and MDA tissue level (Table 2). This was accompanied with significant reduction of GSH (Table 2) and significant increase in tissue level of caspase-3 (Table 1) compared to normal control group. Non diabetic non treated I/R group showed similar qualitative changes but the magnitude of changes was less than diabetic ischemic groups regarding all tested parameters except IL6 which was equi-effective. Treatment with long term oral metformin or short term parenteral Q10 either singly or in combination improved above mentioned parameters in either non diabetic or NAD/STZ diabetic hind limb ischemic reperfusion groups. It was noticed that long term oral metformin in NAD/STZ diabetic hind limb ischemic reperfusion group proved to be better than short term parenteral Q10 as regards all tested parameters except caspase-3 and GSH in which either drug was equieffective. The best results were obtained on combination of both drugs (Table 1 and 2). In non-diabetic ischemic reperfusion groups, metformin and Q10 were equieffective except for reducing level of TNF $\alpha$, IL6, caspase3 , CK-MM and TGF- $\beta$ which were better in metformin treated group (Table 3, Figure $1 \mathrm{~A}, 1 \mathrm{~B}$ and $1 \mathrm{C}$ ). On the other hand, Q10 was better in GSH skeletal muscle tissue level elevation (Table 3 ).

Table 1: Effect of metformin and or co-enzyme q10 in a rat model of hind limb I/R on top of DM type II on average $(\mathrm{Mean} \pm \mathrm{SD})$ serum Hb1AC (\%), CK-MM, Caspase-3 and TGF $\beta 1$ (n=8).

\begin{tabular}{|c|c|c|c|c|}
\hline & $\mathrm{Hb1}_{\mathrm{AC}}(\%)$ & CK-MM (IU/L) & Caspase-3 (Pg/ml) & TGF-ß1 (Pg/ml) \\
\hline Normal control & $4.25 \pm 1$ & $320 \pm 21.1$ & $0.65 \pm 0.01$ & $2.15 \pm 0.86$ \\
\hline $\mathrm{DM}$ & $8.8 \pm 1.9^{a}$ & $700 \pm 35.5^{\mathrm{a}}$ & $10.1 \pm 1.3^{\mathrm{a}}$ & $19.22 \pm 1.5^{\mathrm{a}}$ \\
\hline $\mathrm{DM}+\mathrm{I} / \mathrm{R}$ & $10.4 \pm 2.1^{\mathrm{a}, \mathrm{b}}$ & $4800 \pm 53.8^{\mathrm{a}, \mathrm{b}}$ & $13.1 \pm 2.1^{\mathrm{a}, \mathrm{b}}$ & $25.01 \pm 2.7^{\mathrm{a}, \mathrm{b}}$ \\
\hline $\mathrm{DM}+\mathrm{I} / \mathrm{R}+\mathrm{Q} 10$ & $7.01 \pm 1.3^{\mathrm{a}, \mathrm{b}, \mathrm{c}}$ & $2900 \pm 50.6^{\text {a.b.c }}$ & $7.2 \pm 1.2^{\mathrm{a}, \mathrm{b}, \mathrm{c}}$ & $13.45 \pm 1.8^{\mathrm{a}, \mathrm{b}, \mathrm{c}}$ \\
\hline $\mathrm{DM}+\mathrm{I} / \mathrm{R}+\mathrm{Met}$ & $5.11 \pm 1.8^{b, c, d}$ & $2200 \pm 70.1^{\mathrm{a}, \mathrm{b}, \mathrm{c}, \mathrm{d}}$ & $8.3 \pm 2.3^{\mathrm{a}, \mathrm{b}, \mathrm{c}}$ & $9.21 \pm 1.2^{\mathrm{a}, \mathrm{b}, \mathrm{c}, \mathrm{d}}$ \\
\hline $\mathrm{DM}+\mathrm{I} / \mathrm{R}+\mathrm{Q} 10+\mathrm{Met}$ & $4.5 \pm 0.9^{\mathrm{b}, \mathrm{c}, \mathrm{d}}$ & $1500 \pm 130.8^{\mathrm{a}, \mathrm{b}, \mathrm{c}, \mathrm{d}, \mathrm{e}}$ & $3.7 \pm 0.6^{\text {a.b.c.d.e }}$ & $5.11 \pm 0.9^{\mathrm{a}, \mathrm{b}, \mathrm{c}, \mathrm{d}, \mathrm{e}}$ \\
\hline
\end{tabular}

a: Significant compared with normal control group at $\mathrm{P}>0.05$, b: Significant compared with DM group at $\mathrm{P}>0.05$, c: Significant compared with $\mathrm{DM}+\mathrm{I} / \mathrm{R}$ group at $\mathrm{P}>0.05$, d: Significant compared $\mathrm{DM}+\mathrm{I} / \mathrm{R}+\mathrm{Q} 10$ group at $\mathrm{P}>0.05$, e: Significant compared $\mathrm{DM}+\mathrm{I} / \mathrm{R}+\mathrm{Met}$ group at $\mathrm{P}>0.05$.

Table 2: Effect of metformin and or co-enzyme q10 in a rat model of hind limb I/R on top of DM type II rats on average (Mean \pm SD) SOD activity, GSH, MDA, IL-6 and TNF- $\alpha(n=8)$.

\begin{tabular}{|c|c|c|c|c|c|}
\hline & $\begin{array}{l}\text { SOD } \\
\text { (U/mg protein) }\end{array}$ & $\begin{array}{l}\text { GSH } \\
\text { (nmol/mg protein) }\end{array}$ & $\begin{array}{l}\text { MDA } \\
\text { (pmol/mg protein }\end{array}$ & IL-6(pg/ml) & TNF- $\alpha(\mathrm{pg} / \mathrm{ml})$ \\
\hline Normal control & $2.9 \pm 0.8$ & $65.5 \pm 11.5$ & $46.15 \pm 9.5$ & $18 \pm 6.5$ & $80.57 \pm 11.5$ \\
\hline $\mathrm{DM}$ & $5.7 \pm 1.5^{\mathrm{a}}$ & $20.17 \pm 3.4^{\mathrm{a}}$ & $136.1 \pm 18.7^{a}$ & $57 \pm 5.8^{\mathrm{a}}$ & $285 \pm 20.1^{\mathrm{a}}$ \\
\hline $\mathrm{DM}+\mathrm{I} / \mathrm{R}$ & $9.8 \pm 2.0^{\mathrm{a}, \mathrm{b}}$ & $12.15 \pm 2.1^{\mathrm{a}, \mathrm{b}}$ & $175.2 \pm 13.2^{\mathrm{a}, \mathrm{b}}$ & $75 \pm 8.4^{\mathrm{a}, \mathrm{b}}$ & $390 \pm 19.6^{\mathrm{a}, \mathrm{b}}$ \\
\hline $\mathrm{DM}+\mathrm{I} / \mathrm{R}+\mathrm{Q} 10$ & $3.1 \pm 0.9^{\mathrm{b}, \mathrm{c}}$ & $32 \pm 7.1^{\mathrm{a}, \mathrm{b}, \mathrm{c}}$ & $97.1 \pm 12.1^{\mathrm{a}, \mathrm{b}, \mathrm{c}}$ & $47 \pm 2.3^{\mathrm{a}, \mathrm{b}, \mathrm{c}}$ & $184 \pm 31.2^{\mathrm{a}, \mathrm{b}, \mathrm{c}}$ \\
\hline $\mathrm{DM}+\mathrm{I} / \mathrm{R}+\mathrm{Met}$ & $4.3 \pm 1.1^{\mathrm{a}, \mathrm{b}, \mathrm{c}, \mathrm{d}}$ & $40 \pm 6.8^{\mathrm{a}, \mathrm{b}, \mathrm{c}}$ & $78.6 \pm 8.6^{\mathrm{a}, \mathrm{b}, \mathrm{c}, \mathrm{d}}$ & $38 \pm 3.6^{\mathrm{a}, \mathrm{b}, \mathrm{c}, \mathrm{d}}$ & $145 \pm 12.1^{\mathrm{a}, \mathrm{b}, \mathrm{c}, \mathrm{d}}$ \\
\hline $\mathrm{DM}+\mathrm{I} / \mathrm{R}+\mathrm{Q} 10+\mathrm{Met}$ & $2.2 \pm 0.7^{\mathrm{b}, \mathrm{c}, \mathrm{d}, \mathrm{e}}$ & $55.21 \pm 10.5^{\mathrm{b}, \mathrm{c}, \mathrm{d}, \mathrm{e}}$ & $51.41 \pm 7.2^{\text {b.c.d.e }}$ & $28 \pm 1.9^{\mathrm{a}, \mathrm{b}, \mathrm{c}, \mathrm{d}, \mathrm{e}}$ & $113.3 \pm 10.9^{\mathrm{a}, \mathrm{b}, \mathrm{c}, \mathrm{d}, \mathrm{e}}$ \\
\hline
\end{tabular}

a: Significant compared with normal control group at $\mathrm{P}>0.05$, b: Significant compared with DM group at $\mathrm{P}>0.05$, c: Significant compared with $\mathrm{DM}+\mathrm{I} / \mathrm{R}$ group at $\mathrm{P}>0.05$, d: Significant compared $\mathrm{DM}+\mathrm{I} / \mathrm{R}+\mathrm{Q} 10$ group at $\mathrm{P}>0.05$, e: Significant compared $\mathrm{DM}+\mathrm{I} / \mathrm{R}+\mathrm{Met}$ group at $\mathrm{P}>0.05$.

Table 3: Effect of oral administration of metformin and or parenteral co-enzyme q10 in a rat model of hind limb ischemia reperfusion on average (Mean \pm SD) SOD, GSH, MDA, IL-6 and TNF- $\alpha(n=8)$.

\begin{tabular}{|lllll|l|}
\hline & $\begin{array}{l}\text { SOD } \\
(\mathrm{U} / \mathrm{mg} \text { protein })\end{array}$ & $\begin{array}{l}\text { GSH } \\
(\mathbf{n m o l} / \mathbf{m g} \text { protein) }\end{array}$ & $\begin{array}{l}\text { MDA } \\
(\mathbf{n m o l} / \mathbf{m g} \text { protein })\end{array}$ & IL-6 (pg/ml) & TNF- $\alpha(\mathrm{pg} / \mathrm{ml})$ \\
\hline Normal & $2.9 \pm 0.8$ & $65.5 \pm 11.5$ & $46.15 \pm 9.5$ & $18 \pm 6.5$ & $80.57 \pm 11.5$ \\
\hline I/R & $7.1 \pm 1.6^{\mathrm{a}}$ & $18.2 \pm 3.4^{\mathrm{a}}$ & $120 \pm 17.6^{\mathrm{a}}$ & $78 \pm 18.5^{\mathrm{a}}$ & $320 \pm 11.8^{\mathrm{a}}$ \\
\hline I/R+Q10 & $3.3 \pm 1.2^{\mathrm{b}}$ & $51.2 \pm 13.6^{\mathrm{b}}$ & $55 \pm 13.8^{\mathrm{b}}$ & $49 \pm 12.4^{\mathrm{a}, \mathrm{b}}$ & $170 \pm 13.2^{\mathrm{a}, \mathrm{b}}$ \\
\hline I/R+Met & $4.2 \pm 1.3^{\mathrm{b}}$ & $35 \pm 8.2^{\mathrm{a}, \mathrm{b}, \mathrm{c}}$ & $59 \pm 11.8^{\mathrm{b}}$ & $24 \pm 7.6^{\mathrm{b}, \mathrm{c}}$ & $105 \pm 12.5^{\mathrm{b}, \mathrm{c}}$ \\
\hline I/R+Q10+Met & $3.1 \pm 0.9^{\mathrm{b}}$ & $59.3 \pm 15.8^{\mathrm{b}, \mathrm{d}}$ & $49.04 \pm 15.3^{\mathrm{b}}$ & $21 \pm 7.4^{\mathrm{b}, \mathrm{c}}$ & $99.51 \pm 21.2^{\mathrm{b}, \mathrm{c}}$ \\
\hline
\end{tabular}

a: Significant compared with normal control group at $\mathrm{P}>0.05$, b: Significant compared with $\mathrm{I} / \mathrm{R}$ group at $\mathrm{P}>0.05$, c: Significant compared with $\mathrm{I} / \mathrm{R}+\mathrm{Q} 10$ group at $\mathrm{P}>0.05$, d: Significant compared with $\mathrm{I} / \mathrm{R}+\mathrm{Met}$ group at $\mathrm{P}>0.05$. 

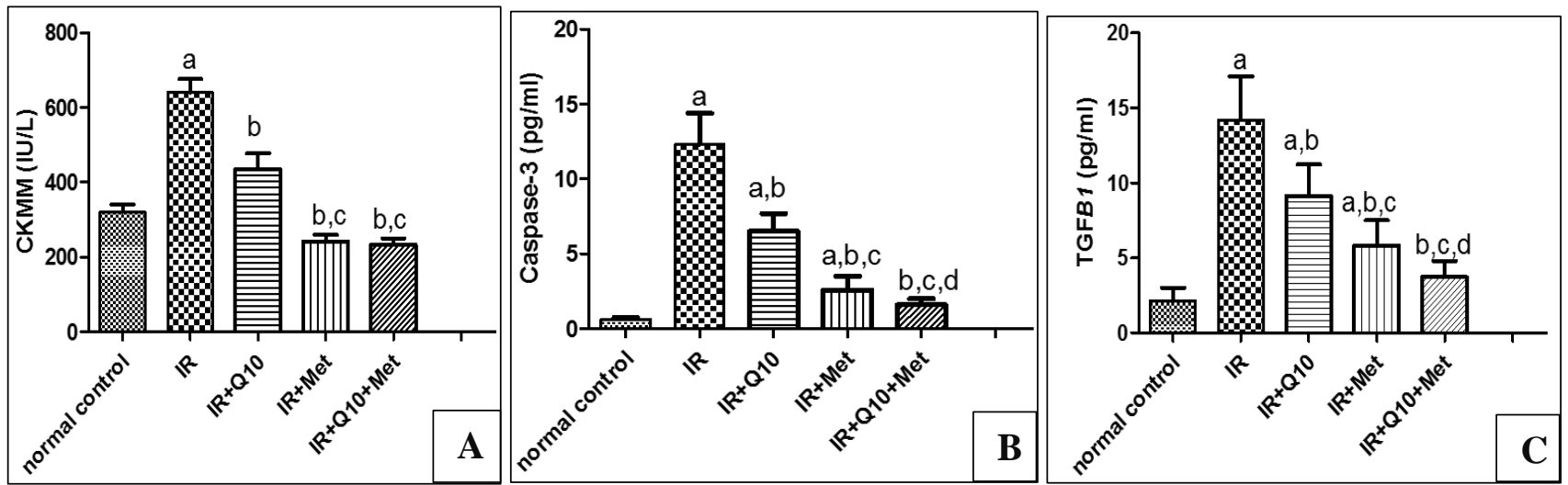

a: Significant compared with normal control group at $\mathrm{P}>0.05$, b: Significant compared with $\mathrm{I} / \mathrm{R}$ group at $\mathrm{P}>0.05$, c: Significant compared with $\mathrm{I} / \mathrm{R}+\mathrm{Q} 10$ group at $\mathrm{P}>0.05$, d: Significant compared with $\mathrm{I} / \mathrm{R}+\mathrm{Met}$ group at $\mathrm{P}>0.05$.

Figure 1: Effect of oral administration of metformin and or parenteral co-enzyme q10 in a rat model of hind limb I/R on average (Mean \pm SD). A) CK-MM (IU/L), B) Caspase-3 (Pg/ml), C) TGF-ß1 (Pg/ml).

\section{DISCUSSION}

In this work, a model of ischemic reperfusion injury was induced in gastrocnemius muscle of rats. Ischemic reperfusion events are common in muscular tissue as it is exposed to anaerobic condition during prolonged muscle contraction followed by reperfusion and regeneration of reducing equivalents during rest. This condition is more obvious in hind limb muscles. ${ }^{16}$

The adopted model of ischemia reperfusion caused marked muscle injury and inflammation manifested as increase release of CK-MM, myokin (IL6) and TNF- $\alpha$ in plasma. This was associated with a state of oxidative stress manifested by marked increase MDA and SOD and reduction of GSH.

This can be explained by the fact that during ischemic period, anaerobic metabolites namely adenosine, uric acid as well as calcium and sodium accumulate. During reperfusion, anaerobic metabolites are re-oxidized into free radicals which activate inflammatory and apoptotic mechanisms. Moreover, increase intracellular calcium results in reduced potential across mitochondrial membrane, increase their permeability to calcium which may lead ultimately to long term mitochondrial dysfunction and permanent apoptotic changes manifested in this work as significant rise in caspase-3. ${ }^{1}$ The role of free radicals as a causative factor for inflammation was demonstrated by Connor EM et al, who showed that reactive oxygen metabolites may also initiate and/or amplify inflammation via up-regulation of several different genes involved in the inflammatory response, such as those that code for pro-inflammatory cytokines and adhesion molecules. ${ }^{17}$ This may occur by the activation of certain transcription factors, such as NF- $\mathrm{BB}$. The latter is a regulator of numerous genes involved in the inflammatory and apoptotic response.
The above-mentioned mechanisms may explain the elevation of TNF-a, TGF- $\beta$ and caspase- 3 level in this work. This was in agreement with Cutrin JC et al, who reported that I/R injury is mainly resulted from generation of ROS especially during reperfusion leading to increased oxidative damage and organ dysfunction. ${ }^{18}$ Moreover, Hunt JV et al, suggested that tourniquet may induce skeletal muscle ischemia-reperfusion injuries via superoxide overproduction and reduced antioxidant activity associated with muscle damage confirmed by high level of CKMM. ${ }^{19}$

In this work, diabetes was induced by streptozotocin and NAD. Streptozotocin is nitrosourea derived alkylating antineoplastic agent that is particularly toxic to the insulinproducing beta cells of the pancreas in mammals. Streptozotocin is similar enough to glucose to be transported into the cell by the glucose transport protein GLUT2 but is not recognized by the other glucose transporters. This explains its relative toxicity to beta cells. ${ }^{20}$ NAD has a protective effect of islet cells against cytotoxic effect of streptozotocin. ${ }^{21}$ Probably through inhibition of ADP-ribose polymerase which not only decreases consumption of NAD+, the substrate of PARP, but also suppressed gene expression of early steps of apoptosis. $^{22}$

Multiple mechanisms may explain diabetes induced oxidative stress. One of them is autoxidation of accumulated $\alpha$ hydroxyglyceralde to $\mathrm{H}_{2} \mathrm{O}_{2}$ and $\alpha$ ketoaldehydes which can form the highly toxic hydroxyl radical. ${ }^{23,24}$

The observed oxidative stress is coupled with significant increase in TNF- $\alpha$ and transforming growth factor $\beta$. This may be linked with hyperglycemia through formation of glycated end products that increase expression proinflammatory genes including TNF- $\alpha .^{25}$ 
Present results are in agreement with Islam who cited that diabetes and its complications caused by the increased levels of free radicals and systemic pro-inflammatory cytokines as well as by an abnormal lipid profile. ${ }^{26}$ Oxidative stress involved in diabetes mellitus could be explained by Daniel EF et al, who reported that the increased extra- and intracellular glucose concentrations results in increased ROS with reduction in the antioxidant body defenses thus causing tissue injury. ${ }^{27}$ Also, Guz G et al, cited that the initial cellular response to hyperglycemia is the generation of ROS followed by rapid activation of the Bax-caspase proteases pathway resulting in induction of apoptotic cell death. ${ }^{28}$

The above-mentioned oxidative stress in either ischemia/reperfusion and type II diabetes may be responsible for the observed elevation of caspase 325 and TGF- $\beta$ observed in DM+I.R group in this work. ${ }^{29,30}$

Regarding the elevated plasma level of interleukin 6 in diabetic model, it is in agreement with Aruna DP et al, who considered it as a marker and a risk factor for development of type II diabetes as it increases gluconeogenesis and lipolysis. ${ }^{31}$ Kristiansen OP et al, correlated its raised level with increase susceptibility for inflammation. ${ }^{32}$

The mechanism of increase IL6 level in type II diabetes may be mediated by hyperglycemia induced advanced glycated end products as a compensatory feedback mechanism against rise of inflammatory mediators such as TNF- $\alpha$.

Induction of $\mathrm{I} / \mathrm{R}$ in diabetic group augmented oxidative stress, TNF- $\alpha$, IL6 elevating effects through combination of above explained causative factors in both tested experimental models. The state of diabetic control was deteriorated due to increase the release of free radicals that augments insulin resistance. CK-MM was markedly increased compared with either model alone which reflected accelerated muscle injury probably due to amplification of ischemic conditions as a result of microvascular complications of diabetes. ${ }^{33}$

Treatment with Q10 markedly ameliorated glycemic control, oxidative stress, pro-inflammatory, pro-apoptotic parameters and muscle injury parameters in tested animal model. This may be attributed to the double action of tested drug in improving mitochondrial electron transport by serving as trans-membrane electron transport intermediate as well direct free radical scavenger. ${ }^{34,35}$ This may explain the observed improvement in oxidative stress state. The latter is the key player in activation of NFkB. Its suppression may explain the observed improvement of proinflammatory, pro-apoptotic parameters. Gholami M et al, demonstrated a cross talk between TNF- $\alpha$ and NF $\kappa B$ which can be activated by TNF- $\alpha$ involved in systemic inflammation. $^{36}$ In response to $\mathrm{TNF}-\alpha, \mathrm{NF}-\kappa \mathrm{B}$ is phosphorylated and translocated into the nucleus. Therefore, specific target genes of pro-inflammatory mediators and cytokine production become immediately up-regulated.

Q10 induced improvement of oxidative stress may also explain the improvement of glycemic control manifested as marked decrease in $\mathrm{HB} 1 \mathrm{AC}$ as free radical formation is one of the triggering factors for insulin resistance. ${ }^{33}$ This is in agreement with Fouad AA et al, who reported that Q10 showed a significant reno-protective effect against STZNAD induced diabetic nephropathy by improving some oxidative stress and inflammatory markers. ${ }^{37}$

Q10 exerted significant improvement of muscle metabolism manifested by reduction of muscle specific cytokine IL6 and muscle specific enzyme creatine phosphokinase. This may be mediated through above explained improvement in mitochondrial function with possible consequent decrease in intracellular calcium in muscle fibers. This result is supported by clinical trials showing that tested drug may improve statin induced myopathy. ${ }^{38}$

The results of metformin treatment in $\mathrm{DM}+\mathrm{I} / \mathrm{R}$ group was in line with that of Q10. Metformin caused significantly more improvement in glycemic control, muscle parameter CKMM and IL6 and most of oxidative stress parameters. Moreover, it exerted marked prophylactic effect in I/R group.

Metformin has antihyperglycemic effect through increase tissue insulin sensitivity due to increase expression of insulin receptors and tyrosine kinase enzyme as well as increase release of glucagon like peptide and inhibition of hepatic glycogenolysis. ${ }^{4}$ In addition, it has an antioxidant effect via inhibition of mitochondrial respiratory chain complex 1 which inhibits both aerobic oxidation and ROS formation. ${ }^{39}$ The consequent low energy state activates AMP kinase pathway which increase glucose uptake, anaerobic oxidation and fatty acid oxidation in skeletal muscles. ${ }^{4}$ This may explain improvement of muscle specific parameters (reduction of CKMM and IL6) in both diabetic and non-diabetic I/R groups. The decrease in free radical synthesis explains the improvement of parameters related to free radical mediated inflammation.

In accordance with the results, Danielle DV et al, reported that metformin can minimize oxidative damage in muscles of hypoinsulinemic rats. ${ }^{39}$ In addition Wilma $\mathrm{HO}$ et al, postulated that metformin down-regulates the scavenger receptors in macrophages in obesity induced type II diabetes in mice resulting in reduction of pro-inflammatory cytokines translocation in macrophages. ${ }^{40}$

Within the dose limits used in this work, metformin proved to be more powerful antihyperglycemic, antioxidant, antiinflammatory than Q10 and equi-effective as regard antiapoptotic effect. This may be related to the fact that Q10 acts mainly through antioxidant effect. While, metformin has additional antihyperglycemic action. 
The protocol of metformin is suitable to prevent slow and prolonged oxidative stress mediated complications in DM. On the contrary that of Q10 is suitable to prevent sudden vascular events in diabetic patients as during vascular surgery. Combination of both tested drugs produces more powerful effect than each other alone. Both drugs were proved to be more effective in diabetic than non-diabetic model of ischemic reperfusion injury. This may be attributed to their specific anti-hyperglycemic effect which is required in treatment of diabetic model in addition to antioxidant effect which works in both diabetic and ischemic reperfusion models.

\section{CONCLUSION}

In conclusion, one may postulate that co-enzyme q10 can be used as add on therapy with metformin in order to decrease the deleterious effects resulted from hind limb ischemia reperfusion. It is recommended to make use of the direct anti-inflammatory activity of metformin and investigate its effect on diseases where inflammation is the main pathophysiological event.

\section{ACKNOWLEDGEMENTS}

Authors would like to thank technical and administrative staff at the Departments of Pharmacology and Clinical Pathology, Faculty of Medicine, Benha University, Egypt for their support during study.

\section{Funding: No funding sources}

Conflict of interest: None declared

Ethical approval: The study was approved by the Institutional Ethics Committee

\section{REFERENCES}

1. Carden DL, Granger DN. Pathophysiology of ischaemia-reperfusion injury. J Pathol. 2000;190(3):255-66.

2. Holcomb JB, McMullin NR, Pearse L, Caruso J, Wade CE, Oetjen-Gerdes L, et al. Causes of death in US Special Operations Forces in the global war on terrorism: 2001-2004. Ann Surg. 2007;245(6):986.

3. Lutchmansingh FK, Hsu JW, Bennett FI, Badaloo AV, McFarlane-Anderson N, Gordon-Strachan GM, et al. Glutathione metabolism in type 2 diabetes and its relationship with microvascular complications and glycemia. PloS One. 2018;13(6):e0198626.

4. Viollet B, Guigas B, Garcia NS, Leclerc J, Foretz M, Andreelli F. Cellular and molecular mechanisms of metformin: an overview. Clin Sci. 2012;122(6):25370.

5. Pajet GE, Barnes JM. Evaluation of drug activities. Pharmacometrics. New York; Academic Press: 1964;1:161.

6. Prem JT, Eppinger M, Lemmon G, Miller S, Nolan D, Peoples J. The role of glutamine in skeletal muscle ischemia/reperfusion injury in the rat hind limb model. Am J Surg. 1999;178(2):147-50.
7. Kakadiya J, Patel D, Shah N. Effect of hesperidin on renal complication in experimentally induced renal damage in diabetic sprague dawley rats. J Ecobiotechnol. 2010;2:45-50.

8. Miles MV. The uptake and distribution of coenzyme Q (10). Mitochondrion. 2007;7:S72-7.

9. Parasuraman S, Raveendran R, Kesavan R. Blood sample collection in small laboratory animals. J Pharmacol Pharmacotherapeutics. 2010;1(2):87.

10. Bradford MM. A rapid and sensitive method for the quantitation of microgram quantities of protein utilizing the principle of protein-dye binding. Analytical Biochem. 1976;72(1-2):248-54.

11. Nolan Y, Maher FO, Martin DS, Clarke RM, Brady MT, Bolton AE, et al. Role of interleukin-4 in regulation of age-related inflammatory changes in the hippocampus. J Biol Chem. 2005;280(10):9354-62.

12. Sun YI, Oberley LW, Li Y. A simple method for clinical assay of superoxide dismutase. Clin Chem. 1988;34(3):497-500.

13. Esterbauer $\mathrm{H}$, Cheeseman KH. Determination of aldehydic lipid peroxidation products: malonaldehyde and 4-hydroxynonenal. Methods Enzymol. 1990;186:407-21.

14. Browne RW, Armstrong D. Reduced glutathione and glutathione disulfide. Free Radical and Antioxidant Protocols. Humana Press. 1998:347-52.

15. Abdel-Wahab AF, Al-Harizy WM. Propofol protects against ischemia/reperfusion injury associated with reduced apoptosis in rat liver. ISRN Anesthesiol. 2013:517478.

16. Jeukendrup AE. Regulation of fat metabolism in skeletal muscle. Ann New York Academy Sci. 2002;967(1):217-35.

17. Conner EM, Grisham MB. Inflammation, free radicals, and antioxidants. Nutrition. 1996;12(4):2747.

18. Cutrín JC, Zingaro B, Camandola S, Boveris A, Pompella A, Poli G. Contribution of $\gamma$ glutamyl transpeptidase to oxidative damage of ischemic rat kidney. Kidney Int. 2000;57(2):526-33.

19. Hunt JV, Dean RT, Wolff SP. Hydroxyl radical production and autoxidative glycosylation. Glucose autoxidation as the cause of protein damage in the experimental glycation model of diabetes mellitus and ageing. Biochem J. 1988;256(1):205-12.

20. Wang Z, Gleichmann H. GLUT2 in pancreatic islets: crucial target molecule in diabetes induced with multiple low doses of streptozotocin in mice. Diab. 1998;47(1):50-6.

21. Manna R, Migliore A, Martin LS, Ferrara E, Ponte E, Marietti G, et al. Nicotinamide treatment in subjects at high risk of developing IDDM improves insulin secretion. Brit J Clin Prac. 1992;46(3):177-9.

22. Kolb H, Burkart V. Nicotinamide in type 1 diabetes. Diab Care. 1999;22:B16.

23. Wolff SP, Dean RT. Glucose autoxidation and protein modification. The potential role of autoxidative glycosylation in diabetes. Biochem J. 1987;245:24350 . 
24. Fu MX, Requena JR, Jenkins AJ, Lyons TJ, Baynes JW, Thorpe SR. The advanced glycation end product, $\mathrm{N}$-(carboxymethyl) lysine, is a product of both lipid peroxidation and glycoxidation reactions. $\mathrm{J}$ Biol Chem. 1996;271(17):9982-6.

25. Dong R,Wang Q, He XL, Chu YK, Lu JG. Role of nuclear factor kappa $\mathrm{B}$ and reactive oxygen species in the tumor necrosis factor-induced epithelialmesenchymal transition of MCF-7 cells. Braz J Med Biol Res. 2007;40:1071-8.

26. Islam IH. Ameliorative effect of apelin on streptozotocin-induced diabetes and its associated cardiac hypertrophy. Alexandria J Med. 2018;54:11927.

27. Francés DE, Ronco MT, Monti JA, Ingaramo PI, Pisani GB, Parody JP, et al. Hyperglycemia induces apoptosis in rat liver through the increase of hydroxyl radical: new insights into the insulin effect. J Endocrinol. 2010;205(2):187.

28. Guz G, Oz E, Lortlar N, UlusuN N, Nurlu N, Demirogullari B, et al. The effect of taurine on renal ischemia reperfusion injury. Amino Acids. 2007;32: 405-11.

29. Lyons RM, Keski-Oja J, Moses HL. Proteolytic activation of latent transforming growth factor-beta from fibroblast-conditioned medium. J Cell Biol. 1998;106:1659-65.

30. Karina BG, Kathryna FR, Ana PF. The role of transforming growth factor-beta in diabetic nephropathy. Int J Med Genetics.2014;180270:1-6.

31. Aruna DP, JoAnn EM, Nader R. C-reactive protein, interleukin 6, and risk of developing type 2 diabetes mellitus. JAMA. 2001;286:327-34.

32. Kristiansen OP, Poulsen TP. Interleukin-6 and diabetes. The Good, the Bad, or the Indifferent? Diab. 2007;54:S114-S124.

33. Tangvarasittichai S. Oxidative stress, insulin resistance, dyslipidemia and type 2 diabetes mellitus. World J Diab. 2015;6:456-80.

34. Seiji M, Kiyohiko D, Kazuo Y, Takashi K. Changes in the levels of endogenous coenzyme Q homologs, $\alpha$ - tocopherol and glutathione in rat liver after hepatic ischemia and reperfusion, and the effect of pretreatment with coenzyme Q10. Biochim Biophysic (BBA)-General Subjects. 1984;797:1-9.

35. Groneberg DA, Kindermann B, Althammer M, Klapper M, Vormann J, Littarru GP, Doring F. Coenzyme Q10 affects expression of genes involved in cell signalling, metabolism and transport in human CaCo-2 cells. Int J Biochem Cell Biol. 2005;37:120818.

36. Gholami M, Khayat ZK, Anbari K, et al. Quercetin ameliorates peripheral nerve ischemia-reperfusion injury through the NF-kappa B pathway. Anat Sci Int. 2017;92(3):330-7.

37. Fouad AA, Al-Sultan AI, Refaie SM, Yacoubi MT. Coenzyme Q10 treatment ameliorates acute cisplatin nephrotoxicity in mice. Env Toxicol Pharmacol. 2010;274:49-56.

38. Qu H, Guo M, Chai H, Wang WT, Gao ZY, Shi DZ. Effects of coenzyme Q10 on statin-induced myopathy: an updated meta-analysis of randomized controlled trials. J Am Heart Assoc. 2018;7:009835.

39. Vilela DD, Peixoto LG, Teixeira RR, Baptista NB, Caixeta DC, Souza AV, et al. The role of metformin in controlling oxidative stress in muscle of diabetic rats. Oxidative Med Cell Longevity. 2016;6978625:1-9.

40. Oliveira WH, Nunes AK, Françaetal MR. Effects of metformin on inflammation and short-term memory in streptozotocin-induced diabetic mice. Brain Res. 2016;1644:149-60.

Cite this article as: Abdel-Aziz EA, Elnoury HA. Increased beneficial outcome of metformin by coenzyme Q10 against experimentally-induced hind limb ischemia reperfusion injury in normal and diabetic rats. Int J Basic Clin Pharmacol 2019;8:98794. 